\title{
EVALUASI PENATAUSAHAAN ASET PADA PEMERINTAH KABUPTEN SARMI
}

\author{
Mutmainnah HS Dimo \\ mutmainnahhsdim0708@gmail.com \\ Syaikhul Falah \\ sehufalah@gmail.com \\ Arius A. Kambu \\ ariusk16@gmail.com
}

\begin{abstract}
ABSTRAK
The research objective was to evaluate the administration of regional property in the Sarmi Regency Government. The administrative aspects that were studied included the aspects of bookkeeping, inventory and reporting. Qualitative and quantitative methods are used to answer the research formulation. The research object consisted of three Regional Apparatus Organizations (OPD), including the Public Works Office, the Health Office and the Education Office. The interviewed informants are treasurers of goods. The interviewed informants were managers of regional property in three regional apparatus organizations

The results of the research show that the Sarmi Regency Government has not fully implemented asset administration in accordance with the Minister of Home Affairs Regulation No. 19 of 2016. It is the only aspect of bookkeeping that has the highest value or has implemented regulations. Furthermore, the reporting and inventory aspects have not been said to have carried out regulatory orders.

The results of this research resulted in the findings of several obstacles, namely: misuse of assets, weak coordination, lack of human resources to handle assets, and limited incentives for asset managers.
\end{abstract}

Keywords: administration of regional property, inventory, bookkeeping, reporting

\section{PENDAHULUAN}

Dalam hal ini tentunya tugas pemerintahan daerah dalam memberikan pelayanan yang baik dan meningkatkan kesejahteraan masyarakat tentunya bukan suatu hal yang mudah, melainkan membutuhkan sarana pendukung seperti sumber daya manusia handal dan aset yang dimiliki oleh pemda. Aset adalah merupakan suatu benda atau barang yang memiliki nilai tukar serta nilai ekonomis yang serta bermanfaat sosial ataupun ekonomi.

Selain itu untuk mengetahui kekayaan negara, termasuk barang milik/kekayaan yang dimiliki daerah dalam rangka meningkatkan dan menyempurnakan administrasi perlengkapan guna untuk menunjang penyelenggaraan semua kegiatan mulai dari pusat sampai di tingkat wilayah, maka peranan penatahusahaan mutlak harus diperlukan. Oleh karena itu pemerintah dituntut untuk dapat mengelola aset dengan sebaik-baiknya, agar menghasilkan informasi yang handal dalam keuangan. 
Salah satu permasalahan utama di Kabupaten Sarmi adalah aset dan terutama aset tetap. Pemerintah Kabupaten Sarmi menyajikan nilai Aset Tetap per 31 Desember 2016 senilai Rp3,29 triliun termasuk di dalamnya nilai Akumulasi Penyusutan senilai Rp 90,6 miliar. Nilai Aset Tetap tidak didukung dengan rincian per jenis Aset Tetap baik jumlah, luas maupun nilai per unit barang sedangkan nilai Akumulasi Penyusutan per31 Desember 2016 bukan merupakan hasil penghitungan di Tahun 2016 melainkan nilai per31 Desember 2015 yang disajikan kembali. Pemerintah Kabupaten Sarmi belum memiliki kebijakanpencatatan, penyajian dan pengungkapan Aset Tetap (BPK, 2017).

Temuan BPK terhadap pengelolaan Aset Tetap sebesar Rp 3,38 triliun tidak disusun melalui proses rekonsiliasi antara Kartu Inventaris Barang (KIB) A, B, C, D, E, dan F dgn belanja modal yang disusun oleh Bidang Aset selaku Pembantu Pengelola Barang. Pembantu Pengelola Barang tidak mengumpul laporan barang milik daerah dari Pengguna Barang pada tingkat SKPD selaku tugas di Bidang Aset. Pemerintah Kabupaten Sarmi belum melakukan penyusutan atas seluruh aset tetap yang dicatatkan dalam Neraca per 31 Desember 2016. Oleh karena itu data aset dari masing-masing SKPD tidak dapat direkonsiliasi dengan data aset yang dimiliki oleh Bidang Aset di BPKAD. Nilai penyusutan dicatat senilai Rp90,6 miliar pada Neraca per 31 December 2015 dan dicatat kembali di Neraca per 31 Desember 2016, baik Bidang Aset tidak dapat menjelaskan rincian dan dokumen pendukungnya. (BPK, 2017).

Temuan BPK pada Kabupaten Sarmi antara lain Inspektorat belum melakukan stock opname Per 31 Desember 2016 terhadap SKPD yang memiliki persediaan, sehingga tidak diketahui jumlah persediaan pada masing-masing SKPD. Selama TA 2016 Pemerintah Kabupaten Sarmi belum memiliki regulasi yang mengatur sistem dan prosedur penataausahaan persediaan, meskipun demikian mengacu dalam ketentuan tentang pengelolaan barang daerah seharusnya pengurus barang dan pengguna barang melaksanakan pencatatan dan inventarisir barang milik daerah yang ada pada penguasaannya. (BPK, 2017). 
Selanjutnya, pengadaan barang yang diperiksa menunjukkan bahwa masingmasing SKPD tidak melakukan penatausahaan dalam bentuk buku catatan atas pengadaan barang yang telah diberikan ke masing-masing SKPD. Hasil penyerahan barang dari rekanan (baik aset tetap maupun persediaan) diterima oleh Panitia Penerima Hasil Pengadaan (PPHP). Pengguna Barang dan Bendahara Barang tidak melakukan pencatatan dan pembukuan. Sehingga tidak mengetahui jumlah barang persediaan yang dikelolanya. Disamping itu, mutasi barang persediaan tidak dilakukan pencatatan dan dilaporkan. Berdasarkan catatan laporan keuangan Pemerintah Kabupaten Sarmi pada Tahun anggaran 2016 hanya Dinas Kesehatan yang melaporkan persediaan yang dikelola. Namun demikian, persediaan yang disajikan tidak didasarkan atas hasil stock opname pada akhir tahun namun hanya didasarkan laporan mutasi barang (BPK, 2017). Oleh karena itu peneliti tertarik untuk meneliti mengenai penatausahaan aset pada Kabupaten Sarmi.

\section{LANDASAN TEORI DAN PENGEMBANGAN HIPOTESIS"}

\section{Landasan Teori}

\section{Teori New Public Management}

Perkembangan Administrasi Publik dewasa ini ditandai dengan terjadinya pergeseran paradigma, Denhardt \& Denhardt, (2003) mencatat 3 paradigma, bermuladari Old Public Administration (OPA), New Public Management (NPM) dan New Public Services (NPS).

Gerakan NPM pada mulanya terjadi di negara-negara maju di benua Eropa, akan tetapi karena suatu gerakan global, sehingga negara-negara berkembangpun juga terkena pengaruh konsep ini. New Public Management (NPM) berperan dalam reformasi sektor public serta erat kaitannya dengan masalah manajemen kinerja sektor publik karena pengukuran kinerja menjadi salah satu prinsip NPM yang utama.

Manajemen public merupakan teori yang beranggapan bahwa praktek manajemensektor swasta adalah lebih baik dibandingkan dengan praktek manajemen pada sektor publik. 
Oleh karena itu,ada beberapa praktik dan teknik yang diterapkan di sektor swasta ke dalam organisasi sektor publik, seperti pengadopsian mekanisme pasar, persaingan tender (Compulsory Competitive Tendering-CCT), dan privatisasi perusahaanperusahaan publik Hughes, (1998) Jackson (1995); Broadbent \& Guthrie, (1992)

\section{Penatausahaan Aset}

\section{Pengertian Penatausahaan}

The Liang Gie, (1984) mengatakan bahwa tata usaha dirumuskan sebagai rangkaian aktivitas menghimpun, mencatat, mengolah, mengganda, mengieim dan menyimpan keterangan-keterangan yang diperlukan dalam setiap organisasi. Tata usaha mempunyai 3 peranan pokok, yaitu: 1) Melayani pelakasanaan pekerjaan-pekerjaan operasional untuk mencapai tujuan dari suatu organisasi. 2) Menyediakan catatan bagi pimpinan organisasi itu untuk mengambil keputusan yang tepat. 3) Membantu menmbangun organisasi.

\section{Pengertian Aset}

Aset (aset) adalah aset ekonomi perusahaan termasuk biaya tangguhan yang dinilai dandiakui sesuai dengan prinsip akuntansi yang berlaku (lkit, 2015: 31). Aset adalah sumber daya yang dimiliki oleh badan usaha atau bisnis. Sumber daya tersebut dapat berupa fisik atau hak yang memiliki nilai ekonomi. Harta Kekayaanadalah benda atau segala sesuatu yang memiliki nilai ekonomi, nilai komersial, atau nilai tukar yang dimiliki oleh suatu badan usaha dan atau perseorangan.

Aset ada dua jenis, yaitu aset berwujud (tangible) dan aset tidak berwujud Siregar., (2004) Aset Tetap Daerah

Menurut PSAP 07,

aset tetap adalah aset berwujud yang memiliki masa manfaat lebih dari12 bulan untuk digunakan dalam kegiatan pemerintahan atau dimanfaatkan oleh mas yarakat umum. Aset tetap pemerintah meliputi a) Aset tetap yang pada entitas pelapor tetapi digunakan oleh entitas lain, seperti instansi pemerintah lainnya; b) Hak atas tanah. 
Penyajian aset dalam neraca sangatlah penting karena sering kali aset merupakan bagian utama dari aset pemerintahan. Aset tetap terdiri dari tanah, gedung, gedung, peralatan dan mesin, jalan, irgasi dan jaringa, aset tetap lainnya, serta konstruksi dalam penyelesaian. Aset tetap lainnya diperoleh dan digunakan untuk kegiatanoperasional pemerintah dan dalam kondisi siap pakai.

\section{Pengelolaan Barang Milik Daerah}

PP No 6/2006 tentang Pengelolaan Barang Milik Daerah menyebutkan bahwa pengelolaan barang milik daerah meliputi perencanaan kebutuhan dan pengagaran, pengadaan, penggunaan, pemanfaatan, keamanan dan pemeliharaan, nilai, penghapusan, pemindahtanganan, penatausahaan, pembinaan, pengawasan, dan pengendalian, sedangkan menurut Permendagri No. 19 tahun 2016 Pengelolaan aset daerah mempunyai serangkaian kegiatan atau siklus terdapat 13 kegiatan/tahapan yaitu

a) Perencanaan kebutuhan dan penganggaran;

b) Pengadaan;

c) Penerimaan, penyimpanan dan penyaluran;

d) Penggunaan; e) Penatausahaan;

f) Pemanfaatan; g) Pemindahtanganan; h) Pembinaan, pengawasan, dan pengendalian; i) Pembiayaan; j) Tuntutan ganti rugi.

\section{Prinsip Dasar Pengelolaan Aset Daerah}

Pemerintah daerah perlu membuat sistem informasi manajemen yang handal agar dapat dijadikan alat untukmembuat laporan pertanggungjawaban, sehingga pengelolaan aset pemerintah dapat berjalan dengan efektif dan efisien serta tercipta transparansi. Selain itu sistem informasi tersebut dapat digunakan sebagai dasar pengambilan keputusan. Mardiasmo, (2004) menjelaskan ada tiga prinsip dasar pengelolaan kekayaan aset daerah yaitu: perencanaan yang tepat, pelaksanaan/ pemanfaatan secara efisien dan efektif, dan pengawasan (monitoring)

\section{Evaluasi Penatausahaan Aset Daerah}


Pada saat melakukan eavaluasi maka informasi yang akan didapatkan adalah terkait dengan selisih suatu progam yang diterapkan, pada saat progam tersebut belum diterapkan dengan ketika progam tersebut dilaksanakan. Evaluasi adalah "suatu proses bukan suatu hasil (produk). Hasil yang diperoleh dari kegiatan evaluasi adalah kualitas sesuatu, baik yang menyangkut tentang nilai atau arti, sedangkan kegiatan untuk sampai pada pemberian nilai dan arti itu adalah evaluasi” Arifin, (2009)

\section{Pengelolaan Barang Milik daerah}

Pengelolaan barang milik daerah membutuhan pengurus barang yang memiliki kompetensi yang memadai yang dapat diukur dari pengetahuan pengalaman serta pelatihan/bimtek Yusuf (2010). Pengetahuan dan kepatuhan akan peraturan-peraturan pengelolaan barang milik daerah akan sangat membantu untuk membatasi ruang gerak pejabat dalam melakukan dan tidak melakukan

pengambilan keputusan yang dapat membuat suatu aset berpindah tangan ata $\mathrm{u}$ tidak berpindah tangan kepada pihak lain, serta yang dapat atau yang tidak dapat diberdayakan/dimanfaatkan untuk kepentingan operasional pemerintaan Yusuf, (2009)Proses yang panjang dalam pengelolaan barang milik daerah memerlukan suatu sistem agar penarikan informasi menjadi lebih cepat, akurat dan dapat dipertanggungjawabkan. Sistem Informasi Manajemen Barang Milik Daerah (SIMDA-BMD) 
diciptakan untuk menggantikan pekerjan manual menjadi pekerjaan dikerjakan secara elektronik.

\section{Pelaksanaan}

pengelolaan barang milik daerah memerlukan sumber daya manusia yang kualitas dan kuantitas yang memadai. Menurut Suharto, (2012), kualitas sumber daya manusia

merupakan kemampuan dari pegawai dalam menjalankan proses pengelolaan dilihat dari kemahiran seseorang, latar belakang pendidikan, persyaratan yang harus diikuti untuk dapat menjalankan proses pengelolaan, pelatihan-pelatihan, masalah professional dan sosialisassi peraturan yang mengalami perubahan. Kualitas aparatur daerah menurut Koswara, (2001):

merupakan kemampuan professional dan keterampilan teknis para pegawai yan g termasuk kepada unsur staf dan pelaksana di lingkungan pemerintah daerah. Hal ini sangat diperlukan agar manajemen pemerintahan dalam otonomi daerah dapat berlangsung secara efe ktif dan efisien, tetapi juga kualitas para pegawai yang harus diukur dengan melihat latar bela kang pendidikan, keterampilan, pengalaman kerja, jenjang kepangkatan dan status kepegawaian.

\section{METODOLOGI PENELITIAN}

\section{Lokasi Penelitian}

Penelitian ini dilakukan di Pemerintah Kabupaten Sarmi dengan lokasi penelitian pada tiga Organisasi Perangkat Daerah (OPD) yaitu 
Dinas Pekerjaan Umum (PU), Dinas Pendidikan \& Pengajaran (P\&P) dan Dinas Kesehatan.

\section{Populasi dan Sampel Penelitian}

Populasi dalam penelitian ini adalah seluruh pegawai yang terlibat dalam pengelolaan aset, terdiri dari kepala dan sekretaris SKPD, kepala bidang/kepala bagian, kepala subbidang/kepala subbagian, staf, dan pengurus barang, ditambah mantan kepala bidang. Adapun sampel penelitian ini berjumlah 8 orang.

\section{Jenis Penelitian dan Sumber Data}

$\begin{array}{lll}\text { Pada } & \text { kenelitian } & \text { kali }\end{array}$ peneliti memilih jenis penelitian deskriptif kualitatif maka data yang diperoleh haruslah mendalam, jelas dan spesifik. Sumber data yang digunakan dalam penelitian ini adalah data primer, dengan metode pengumpulan data dengan cara observasi, dokumentasi, dan wawancara.

\section{Metode Analisis Data}

Teknik yang digunakan dalam penelitian ini adalah studi kasus dengan teknik analisis deskriptif. Untuk itu, evaluasi dan analisis yang dilakukan dapat memberikan suatu perbandingan (komparasi) kriteria dari penatausahaan asset tetap menurut Permendagari No 19 tahun 2016 dengan penatausahaan tetap yang diterapkan di Pemerintah Pemerintah Kabupaten Sarmi sebagai suatu realita yang akan diteliti.

\section{HASIL PENELITIAN DAN PEMBAHASAN}

\section{Analisis Data}

\section{Evaluasi Penatausahaan}

Indeks dalam penelitian ini merupakan angka yang menunjukan perbandingan kriteria-kriteria yang ditetapkan berdasarkan peraturan perundang-undangan. Penilainnya adalah sebagai 
berikut jika kriteria sesuai dengan fakta yang terjadi dilapangan (ada/ya) maka diberi skor 1 (satu), jika kriteria belum sesuai (tidak ada/tidak) maka diberi skor 0 (nol). Ritonga \& Alam, (2010).

\section{Evaluasi Penatausahaan Aset}

Kelengkapan pengisian dokumen terdiri dari 6 . Jenis dokumen yang dijadikan dasar dalam penatausahaan asset tetap berdasarkan pada permendagri 17 tahun 2007. Masing-masing dokumen memiliki kriteria pada permendagri 17 tahun 2007. Masing-masing dokumen memiliki kriteria yag berbeda. Masing-masing dokumen di evaluasi berdasarkan kelengkapan pengisian dokumen tersebut berdasarkan kriteria yang ditetapkan. Kelengkapan pengisian dokumen untuk untuk Kartu Inventaris Barang (Tanah) terdiri dari 11 kriteria, Kartu Inventaris Barang (Mesin dan Peralatan) terdiri dari 8 kriteria, Kartu Inventaris Barang (gedung dan Bangunan) terdiri dari 13 kriteria, Kartu Inventaris Barang ( jalan, irigasi dan jaringan) terdiri dari 11 kriteria, Kartu Inventaris Barang (Aset Tetap Lainnya) terdiri dari 7 kriteria, Kartu Inventaris Barang (Konstrukdi Dalam Pengerjaan) terdiri dari 11 kriteria.

\section{Menghitung Tingkat Kesesuaian}

Tingkat kesesuaian dalam evaluasi ini dihitung dengan menggunakan teknik deskriptif persentase yaitu teknik analisis dengan menggunakan teknik analisis dengan membuat persentase dari data yanga da, kemudian dideskripsikan.

Tabel Tingkat Kesesuaian
\begin{tabular}{|l|c|}
\hline \multicolumn{1}{|c|}{ Keterangan } & $\begin{array}{c}\text { Tingkat } \\
\text { Kesesuaian }\end{array}$ \\
\hline Sangat Sesuai & $81-100 \%$ \\
\hline Sesuai & $61-80 \%$ \\
\hline Cukup Sesuai & $41-60 \%$ \\
\hline Tidak Sesuai & $21-40 \%$ \\
\hline Sangat Tidak Sesuai & $0-20 \%$ \\
\hline
\end{tabular}

\section{Pembahasan}

Evaluasi Pembukuan, Inventarisasi dan Pelaporan Aset Tetap

\section{a. Pembukuan Aset Tetap}


Berdasarkan hasil pengolahan data, dapat dilihat bahwa nilai persentase untuk pembukuan aset tetap pada Kantor Dinas Pekerjaan Umum Kabupaten Nomor 19 tahun 2016 memiliki tingkat kesesuaian yaitu sebesar $75 \%$ atau termasuk kategori sesuai dengan Peraturan

Menteri Dalam Negeri Nomor 19 tahun 2016.

Rekapitulasi Penatausahaan Aset Tetap Kabupaten Sarmi

\begin{tabular}{|c|c|c|c|c|c|c|c|c|c|c|}
\hline NO & $\begin{array}{c}\text { PENATAUSAHAAN ASET } \\
\text { TETAP }\end{array}$ & \begin{tabular}{|c|} 
Skor \\
Maksimal
\end{tabular} & \multicolumn{2}{|c|}{ DINAS PU } & \multicolumn{2}{|c|}{ DINAS P \&P } & \multicolumn{2}{|c|}{ DINKES } & \multicolumn{2}{|c|}{ RATA-RATA } \\
\hline & 1 Pembukuan Aset Tetap & 20 & 15 & $75 \%$ & 17 & $85 \%$ & 14 & $70 \%$ & 15,3 & $76,70 \%$ \\
\hline & 2 InventarisasiAsetTetap & 26 & 14 & $54 \%$ & 7 & $27 \%$ & 10 & $38 \%$ & 10,3 & $39,70 \%$ \\
\hline & 3 PelaporanAsetTetap & 23 & 18 & $79 \%$ & 13 & $56 \%$ & 4 & $17 \%$ & 11,7 & $50,70 \%$ \\
\hline
\end{tabular}

Sumber : Data diolah, 2019

Berdasarkan hasil pengolahan data yang telah disajikan dilihat bahwa nilai persentase untuk pembukuan aset tetap pada Kantor Dinas P\&P Kabupaten Nomor 19 tahun 2016 memiliki tingkat kesesuaian sebesar $85 \%$ atau dapat dikategorikan sangat sesuai dengan Peraturan Menteri Dalam Negeri Nomor 19 tahun 2016. Berdasarkan tabel diatas pula dapat dilihat bahwa nilai persentase untuk pembukuan aset tetap pada Kantor Dinas Kesehatan Kabupaten Nomor 19 tahun 2016 memiliki tingkat kesesuaian yaitu sebesar $70 \%$ atau termasuk kategori sesuai dengan Peraturan Menteri Dalam Negeri Nomor 19 tahun 2016. Pada tabel 4.2 juga menjelaskan bahwa dinas pendidikan memperoleh tingkat kesesusian yang terttinggi pada pembukuan sebesar $85 \%$. Hal ini menjelaskan tentang kepatuhan dinas pendidikan dalam melaksanakan pembukuan.

Bila dilihat dari uraian penjelasan mengenai tingkat kesesuaian diatas, hal itu dapat dikatakan belum mengimplementasikan hampir seluruh kriteria yang tetapkan dalam kegiatan pelaksanaan pembukuan aset tetap berdasarkan permendagri 19 tahun 2016. Salah satu temuan BPK terkait permasalahan pembukauan Kepala SKPD tidak melakukan pendaftaran dan pencatatan BMD ke dalam Daftar Barang 
Pengguna (DBP) menurut penggolongan dan kodefikasi barang untuk dimuat dalam Kartu Inventaris Barang. Pemerintah Kabupaten Sarmi belum memiliki Daftar Aset sehingga nilai Aset Tetap senilai Rp3.292.809.716.880,00 merupakan nilai realisasi anggaran belanja modal dan belum membuat rincian per jenis Aset Tetap.

\section{Evaluasi Pembukuan}

\begin{tabular}{|c|c|c|c|c|c|}
\hline \multicolumn{2}{|r|}{ INDIKATOR } & DINAS PU & DINAS P \&P & DINKES & RATA-RATA \\
\hline 1 & Pembukuan Aset Tetap & & & & \\
\hline 1 & SKPD memiliki Daftar BarangPengguna (DBP)/daftaraset SKPD & 0 & 1 & 1 & 0,7 \\
\hline 2 & $\begin{array}{l}\text { Pengurus barang melakukan pendaftaran dan pencatatan } \\
\text { barang milik daerah ke dalam Daftar Barang Pengguna } \\
\text { (DBP)/daftar aset SKPD }\end{array}$ & 1 & 1 & 1 & 1,0 \\
\hline 3 & $\begin{array}{l}\text { SKPD melakukan pendaftaran dan pencatatan aset kedalam } \\
\text { Daftar Barang Pengguna(DBP)/daftaraset SKPD menurut } \\
\text { penggolongan dan kodefikasi barang. }\end{array}$ & 1 & 0 & 0 & 0,3 \\
\hline 4 & $\begin{array}{l}\text { Dokumen kepemilikan selain tanah dan/ataubangunan disimpan } \\
\text { oleh SKPD }\end{array}$ & 0 & 0 & 0 & 0,0 \\
\hline 5 & SKPD memiliki Kartu Inventaris Barang (KIB). & 1 & 1 & 1 & 1,0 \\
\hline 6 & SKPD memiliki Kartu Inventaris Ruangan (KIR) & 1 & 1 & 0 & 0,7 \\
\hline 7 & SKPD memiliki Daftar Barang Pengguna (DBP)/daftar aset SKPD & 0 & 1 & 1 & 0,7 \\
\hline 8 & $\begin{array}{l}\text { Pengurus barang melakukan pendaftaran dan pencatatan sesuai } \\
\text { format Kartu Inventaris Barang (KIB) A untuk tanah }\end{array}$ & 0 & 1 & 1 & 0,7 \\
\hline 9 & $\begin{array}{l}\text { Pengurus barang melakukan pendaftaran dan pencatatan sesuai } \\
\text { format Kartu Inventaris Barang (KIB) B untuk Peralatan dan } \\
\text { Mesin }\end{array}$ & 1 & 1 & 1 & 1,0 \\
\hline 10 & $\begin{array}{l}\text { Pengurus barang melakukan pendaftaran dan pencatatan sesuai } \\
\text { format Kartu Inventaris Barang (KIB) C untuk gedung dan } \\
\text { bangunan }\end{array}$ & 1 & 1 & 1 & 1,0 \\
\hline 11 & $\begin{array}{l}\text { Pengurus barang melakukan pendaftaran dan pencatatan sesuai } \\
\text { format Kartu Inventaris Barang (KIB) D untuk Jalan, Jaringan dan } \\
\text { irigasi }\end{array}$ & 1 & 1 & 0 & 0,7 \\
\hline 12 & $\begin{array}{l}\text { Pengurus barang melakukan pendaftaran dan pencatatan sesuai } \\
\text { format Kartu Inventaris Barang (KIB) E untuk aset tetap lainnya }\end{array}$ & 1 & 1 & 1 & 1,0 \\
\hline
\end{tabular}




\section{b. Pelaksanaan Inventarisasi Aset}

Berdasarkan hasil pengolahan data pada tabel 1 diatas, dapat dilihat bahwa nilai persentase untuk pelaksanaan inventarisasi aset pada Kantor Dinas memiliki tingkat kesesuaian yaitu sebesar $54 \%$ atau termasuk kategori cukup sesuai dengan Peraturan Menteri Dalam Negeri Nomor 19 tahun 2016. Pengolahan data pada tabel 1 diatas juga dapat dilihat bahwa nilai persentase untuk pelaksanaan inventarisasi aset pada Kantor Dinas P\&P Kabupaten memiliki tingkat kesesuaian sebesar $27 \%$ atau dapat dikategorikan tidak sesuai dengan Peraturan Menteri Dalam Negeri Nomor 19 tahun 2016. serta dapat diketahui bahwa nilai persentase untuk pelaksanaan inventarisasi aset pada Dinas Kesahatan memiliki tingkat kesesuaian yaitu sebesar $38 \%$ atau termasuk kategori tidak sesuai dengan Peraturan Menteri Dalam Negeri Nomor 19 tahun 2016.

Bila dilihat dari uraian penjelasan mengenai tingkat kesesuaian diatas, hal itu dapat dikatakan terjadi karena SKPD dilingkungan Pemerintah Kabupaten Sarmi belum 
sepenuhnya mengimplementasikan seluruh kriteria yang tetapkan dengan baik dalam kegiatan pelaksanaan inventarisasi aset berdasarkan Permendagri 19 tahun 2016. Pada kantor Dinas P\&P terdapat 3 kriteria yang belum diterapkan, pada Kantor Dinas Pendidikan dan Kebudayaan Kabupaten Sarmi 18 kriteria yang belum diterapkan.

Evaluasi Inventarisasi

\begin{tabular}{|c|c|c|c|c|c|}
\hline \multicolumn{2}{|r|}{ INDIKATOR } & DINAS PU & DINAS P \&P & DINKES & $\begin{array}{l}\text { RATA- } \\
\text { RATA }\end{array}$ \\
\hline II & \multicolumn{5}{|l|}{ Pelaksanaan Inventarisasi Aset } \\
\hline 2 & $\begin{array}{l}\text { Setiap barang inventaris milik daerah (Aset) diberikan kodefikasi untuk } \\
\text { mengamankan dan menjelaskan status kepemilikan pada masing-masing } \\
\text { pengguna/SKPD }\end{array}$ & 1 & 1 & 0 & 0,7 \\
\hline 3 & $\begin{array}{l}\text { SKPD memiliki Buku Inventaris barang yang menunjukkan semua kekayaan } \\
\text { daerah yang yang bersifat kebendaan, baik bergerak maupun yang tidak } \\
\text { bergerak }\end{array}$ & 1 & 0 & 0 & 0,3 \\
\hline 4 & $\begin{array}{l}\text { Buku Inventaris meliputi lokasi, jenis/merk type, jumlah, ukuran, harga, } \\
\text { tahunpembelian, asal barang, keadaan barang dsb }\end{array}$ & 1 & 0 & 0 & 0,3 \\
\hline 7 & $\begin{array}{l}\text { Pengguna melaporkan buku inventaris ke pembantu pengelola (bagian aset) di } \\
\text { akhi rtahuna nggaran }\end{array}$ & 1 & 0 & 1 & 0,7 \\
\hline 8 & $\begin{array}{l}\text { PembantuPengelola (bidangaset) memilikiRekapitulasiBukulnventaris yang } \\
\text { lengkap }\end{array}$ & 1 & 0 & 0 & 0,3 \\
\hline 9 & Pembantu Pengelola (bidang aset) memiliki Buku Induk Inventaris & 1 & 0 & 1 & 0,7 \\
\hline 10 & $\begin{array}{l}\text { Pembantu pengelola barang mengkompilasi Buku Inventaris menjadi buku induk } \\
\text { inventaris }\end{array}$ & 1 & 0 & 1 & 0,7 \\
\hline 11 & $\begin{array}{l}\text { Rekapitulasi Buku Induk Inventaris ditandatangani oleh pengelola atau } \\
\text { pembantu pengelola }\end{array}$ & 1 & 0 & 1 & 0,7 \\
\hline 12 & $\begin{array}{l}\text { Daftar Rekapitulasi inventaris disusun oleh pembantu pengelola dengan } \\
\text { menggunakan bahan dari rekapitulasi inventaris barang yang disampaikan oleh } \\
\text { pengguna/SKPD }\end{array}$ & 1 & 1 & 1 & 1,0 \\
\hline
\end{tabular}




\section{c. Pelaksanaan Pelaporan}

Berdasarkan hasil perhitungan persentase untuk pelaksanaan pelaporan aset tetap pada tabel 1 diatas, dapat dilihat bahwa pada Kantor Dinas PU memiliki tingkat kesesuaian yaitu sebesar $79 \%$ atau termasuk kategori sesuai dengan Peraturan Menteri Dalam Negeri Nomor 19 tahun 2016. Dapat dilihat juga bahwa nilai presentase untuk pembukuan aset tetap pada Kantor Dinas P\&P memiliki tingkat kesesuaian sebesar $56 \%$ atau dapat dikategorikan cukup sesuai dengan Peraturan Menteri Dalam Negeri Nomor 19 tahun 2016. Serta untuk pelaksanaan pelaporan aset tetap pada DINKES Kabupaten Sarmi memiliki tingkat kesesuaian yaitu hanya sebesar $17 \%$ atau termasuk kategori sangat tidak sesuai dengan Peraturan Menteri Dalam Negeri Nomor 19 tahun 2016.

Berdasarkan hasil perhitungan persentase pada tabel diatas pula, dapat dilihat bahwa Bila dilihat dari uraian penjelasan mengenai tingkat kesesuaian diatas, hal itu 
dapat dikatakan terjadi karena SKPD dilingkungan Pemerintah belum sepenuhnya mengimplementasikan seluruh kriteria yang tetapkan dengan baik dalam kegiatan pelaksanaan pelaporan aset tetap berdasarkan Permendagri 19 tahun 2016. Pada kantor Dinas PU sendiri terdapat 9 kriteria yang belum diterapkan, pada Kantor Dinas Pendidikan dan Kebudayaan terdapat sebanyak 22 kriteria yang belum diterapkan.

Evaluasi Pembukuan Aset Tetap, Inventarisasi Aset dan Pelaporan Aset Tetap, memiliki total skor rata - rata masing - masing SKPD yaitu untuk Kantor BPKAD mencapai 82 \%, Kantor Dinas Pekerjaan Umum mencapai 99 \%, dan Kantor Dinas Pendidikan dan Kebudayaan mencapai 30 \%. .

Evaluasi Pelaporan

\begin{tabular}{|c|c|c|c|c|c|}
\hline & INDIKATOR & DINAS PU & DINAS P \&P & DINKES & RATA-RATA \\
\hline IIII & PelaksanaanPelaporanAset & & & & \\
\hline 1 & SKPD memilikilaporanMutasiBarangsemesteran & 0 & 0 & 1 & 0,3 \\
\hline 2 & SKPD memilik iDaftar Mutasi Baran gtahunan & 0 & 0 & 1 & 0,3 \\
\hline 3 & SKPD memiliki Rekapitulas Daftar Mutasi Barang & 1 & 0 & 1 & 0,7 \\
\hline 4 & SKPD memiliki Daftar Usulan Barang yang Akan Dihapus & 1 & 0 & 0 & 0,3 \\
\hline 5 & $\begin{array}{l}\text { Pengguna/Kuasa pengguna barang sudah membuat dan menyampaikan laporan } \\
\text { atas mutasi barang kepada pembantu pengelola barang }\end{array}$ & 1 & 1 & 0 & 0,7 \\
\hline 6 & $\begin{array}{l}\text { Daftar mutasi barang yang dilaporkan oleh Pengguna/Kuasa pengguna barang } \\
\text { sudah menjelaskan alasan penyebab bertambah dan berkurangnya barang milik } \\
\text { daerah/aset tetap }\end{array}$ & 0 & 0 & 0 & 0,0 \\
\hline 7 & $\begin{array}{l}\text { Penguna/Kuasa Pengguna Barang menyampaikan laporan pengguna barang } \\
\text { semesteran, tahunan, dan } 5 \text { (lima) tahunan kepada pengelola BMD melalui } \\
\text { pembantu pengelola BMD }\end{array}$ & 0 & 0 & 0 & 0,0 \\
\hline 8 & $\begin{array}{l}\text { Mutasi barang bertambah dan/atau berkurang pada SKPD setiap semester, } \\
\text { dicatat secara tertib pada Laporan Mutasi Barang }\end{array}$ & 0 & 0 & 0 & 0,0 \\
\hline 9 & $\begin{array}{l}\text { Mutasi barang bertambah dan/atau berkurang pada SKPD setiap tahun, dicatat } \\
\text { secara tertib pada Daftar Mutasi Barang }\end{array}$ & 1 & 0 & 0 & 0,3 \\
\hline 10 & $\begin{array}{l}\text { Pembantu Pengelola (bidangaset) memiliki Laporan Barang Milik Daerah } \\
\text { (LBMD). }\end{array}$ & 1 & 1 & 0 & 0,7 \\
\hline
\end{tabular}


Berikut ini merupakan tabel hasil penilaian dari masing - masing kriteria untuk pelaksanaan kegiatan pembukuan, inventarisasi, dan pelaporan menegenai penatausahaan aset

Rekapitulasi Evaluasi Aset Per OPD

\begin{tabular}{|c|c|c|c|c|c|c|c|c|c|}
\hline No & $\begin{array}{l}\text { PENATAUSAHAAN } \\
\text { ASET TETAP }\end{array}$ & \multicolumn{2}{|c|}{ DINAS PU } & \multicolumn{2}{|c|}{ DINAS P \&P } & \multicolumn{2}{|r|}{ DINKES } & \multicolumn{2}{|c|}{ RATA-RATA } \\
\hline 1 & PembukuanAsetTetap & $75 \%$ & Sesuai & $85 \%$ & SangatSesuai & $70 \%$ & Sesuai & $76,70 \%$ & Sesuai \\
\hline 2 & InventarisasiAsetTetap & $54 \%$ & CukupSesuai & $27 \%$ & TidakSesuai & $38 \%$ & TidakSesuai & $39,70 \%$ & TidakSesuai \\
\hline 3 & PelaporanAsetTetap & $79 \%$ & sesuai & $56 \%$ & Cukupsesuai & $17 \%$ & SangatTidakSesuai & $50,70 \%$ & Cukupsesuai \\
\hline
\end{tabular}

\section{Kendala - Kendala Penatausahaan Aset}

Berdasarkan hasil pemeriksaan BPK (2017) atas laporan keuangan pemerintah kabupaten Sarmi ditemukan beberapa permasalahan sebagai berikut a) Pemerintah Kabupaten Sarmi belum memiliki Peraturan Daerah mengenai pengelolaan Barang Milik Daerah Reviu atas regulasi yang dimiliki Pemerintah Kabupaten Sarmi dan hasil kuesioner pengelolaan barang milik daerah diketahui Pemerintah Kabupaten Sarmi belum 
memiliki peraturan yang mengatur pengelolaan barang milik daerah. Peraturan terkait aset tersebut meliputi penetapan umur manfaat, penyusutan aset, kapitalisasi aset dan tatacara penghapusan barang milik daerah; b) Perencanaan Kebutuhan dan Penganggaran Barang Milik Daerah belum memadai.

\section{a. Penyalahgunaan Aset : Tindakan Oknum}

Permasalahan penatausahaan aset tetap yang terjadi di Pemerintah Kabupaten Nomor 19 tahun 2016, tidak terlepas dari berbagai macam persoalan yang terjadi di seluruh SKPD. Salah satu permasalahan yang dominan adalah adanya tindakan penyalahgunaan aset oleh para oknum, seperti mengalihkan dan membawa mutasi kendaraan tanpa sepengetahuan dan koordinasi dengan SKPD yang bersangkutan, dan tanpa melalui prosedur penyerahan yang didukung Berita Acara Serah Terima Barang (BASTB). Penyebab lainnya adalah kurangnya kesadaran dari oknum pegawai yang memegang kendaraan dinas di mana yang bersangkutan menginginkan agar kendaraan tersebut tetap menjadi kendaraan operasional di SKPD barunya.

Pengalihan kendaraan dinas tanpa sepengetahuan pengurus barang dan tanpa prosedur penyerahan berita acara serah terima barang dapat menyebabkan pencatatan dan pelaporan SKPD menjadi tidak tertib dan akurat, karena akan terjadi ketidaksesuaian antara jumlah kendaraan yang tercatat di Kartu Inventaris Barang (KIB) dengan jumlah fisik aset yang ada. Akibatnya, untuk mengetahui keberadaan aset tersebut harus dilakukan penelusuran kembali atas aset yang dibawa atau dimutasi ke SKPD lain.

Setiap penyelenggara negara pasti merasa malu jika tugas dan fungsinya tidak sesuai dengan harapan masyarakat dan harus terus mengasah kepekaan "akal sehat" nya agar lebih berhati-hati dan tidak lagi mencederai perasaan masyarakat. Begitu pula masyarakat harus menumbuhkan rasa kepedulian, partisipasi, kritik dan rasa memiliki (sense of belonging) terhadap 
penyelenggaraan pelayanan pemerintah, mengubah pola pikir dari justifikasi apa yang umum menjadi menyesuaikan hak Pacini, Hopwood, \& Sinclair, (2016) Berkembangnya rasa "memiliki“ bukanlah tanpa sebab karena sebagian besar biaya yang dikeluarkan untuk melakukan pemeliharaan aset tersebut berasal dari kantung atau biaya pribadi pemegang aset. Apalagi dalam melakukan pemeliharaan kendaraan dinas roda empat, biaya yang dianggarkan oleh SKPD dianggap belum sebanding dengan biaya yang dikeluarkan oleh pemegang aset. Alasan itulah yang melatarbelakangi tindakan oknum sehingga dengan sengaja menunda untuk mengembalikan kendaraan dinas ke SKPD asal,sekalipun telah pensiun. Faktor lain yang dianggap sebagai kendala dalam penatausahaan aset tetap adalah kurang maksimalnya penyampaian laporan aset oleh SKPD.

\section{b. Lemahnya Koordinasi}

Kurangnya koordinasi ini juga terjadi di SKPD Y. Hal ini dikatakan oleh HK (pengurus barang SKPD Y). Di mana bendahara pengeluaran kurang melibatkan pengurus barang pada setiap pengadaan barang/jasa di SKPD tersebut. Dalam melakukan pengadaan barang/jasa, bendahara pengeluaran terkesan tidak transparan dan tidak bekerja sama dengan pengurus barang. Bahkan, untuk mendapatkan dokumen bukti belanja pun berupa kontrak dan lainnya, bendahara pengeluaran selalu menunda pemberian dokumen tersebut.

Koordinasi merupakan hal penting yang harus dilakukan terutama dalam internal SKPD karena merupakan suatu kebutuhan dalam mengomunikasikan setiap pelaksanaan tugas masing-masing individu yang ada di SKPD, baik antara pengurus barang dengan bendahara pengeluaran maupun dengan atasannya sehingga tujuan organisasi dapat tercapai. Koordinasi yang kurang baik akan mengakibatkan adanya saling lempar tanggung jawab dan merasa bahwa ruang lingkup pekerjaan tersebut bukan merupakan tugas dan wewenangnya.

\section{c. Kurangnya Sumber Daya Manausia (SDM)}


Terkait Sumber Daya Manusia (SDM) yang mengelola aset, rata-rata SKPD mengeluhkan jumlah tenaga pembantu pengelola aset yang masih kurang dan belum seimbang dengan beban kerja yang dilaksanakan. Jumlah tenaga yang ada di SKPD tersebut dirasakan masih kurang karena yang melakukan kegiatan penatausahaan aset tetap di SKPD $\mathrm{Y}$ hanya dua orang saja, yaitu pengurus barang dan staf administrasi. Sementara itu, SKPD tersebut memiliki ribuan aset yang perlu dicatat, diinventarisasi dan dilaporkan oleh tenaga pengelola aset. Belum lagi jika pengurus barang dihadapkan pada permasalahan komunikasi internal SKPD yang belum selaras sehingga sering mengala mi keterlambatan dalam menyusun laporan aset, disebabkan keterlambatan penyerahan data dan dokumen belanja oleh bendahara pengeluaran ataupun bagian SKPD.

Kekurangan jumlah tenaga pengelola aset tidak hanya dirasakan oleh SKPD-SKPD, tetapi juga oleh sekolah-sekolah yang ada di Kabupaten Sarmi. Hal ini dikemukakan oleh HS ketika ditanya terkait kendala SDM. Lain halnya dengan kondisi yang ada di SKPD Z. Walaupun kekurangan tenaga administrasi yang membantu kegiatan penatausahaan aset dan terkendala pada pembantu pengurus barang yang ada di bagian-bagian karena masih ada yang belum bisa mengoperasikan komputer, pengurus barang di SKPD Z dapat melakukan tugasnya dengan baik. Hal ini disebabkan pengurus barang EC pernah menduduki jabatan yang sama sebelumnya di SKPD lain yang juga memiliki total aset yang cukup besar.

Saat ini Kabupaten Sarmi telah menggunakan aplikasi SIMDA-BMD dalam melakukan penatausahaan asetnya. Tentusumber daya yang dibutuhkan untuk dijadikan sebagai pengurus barang adalah minimal yang bisa mengoperasikan komputer. SKPD X selalu mengupayakan agar yang menjadi calon pengurus barang adalah orang-orang yang bisa menggunakan komputer.

\section{d. Kurangnya insentif.}


Permasalahan dalam kegiatan penatausahaan aset tetap di SKPD umumnya juga disebabkan oleh ketidakseimbangan antara beban tugas yang dikerjakan dan besarnya insentif yang diterima oleh pengurus barang. Pemberian insentif bertujuan antara lain untuk mendorong semangat kerja karyawan dan meningkatkan produktivitas dalam bekerja Botosan \& Huffman, (2015).

Untuk itu, hendaknya organisasi atau SKPD mempertimbangkan besarnya nilai insentif yang diberikan dengan banyaknya tugas yang dikerjakan oleh pengurus barang karena hal tersebut dapat memotivasi diri sekaligus menghasilkan laporan aset yang maksimal. Karena bisa jadi, jika pengurus barang SKPD malas dan sering terlambat dalam menyampaikan laporannya, salah satu alasannya adalah disebabkan oleh minimnya jumlah insentif yang diberikan SKPD.

Di sini juga diperlukan adanya perhatian pimpinan dalam melihat, merasakan, dan memahami tugas dan tanggung dari pengurus barang sebagai salah satu yang berperan dalam mendapatkan predikat WTP.

Beberapa permasalahan di atas memang menjadi kendala dalam penatausahaan aset tetap, tetapi pihak pemerintah daerah juga telah berupaya untuk melakukan langkahlangkah dalam meminimalisasi kendala tersebut. Hal ini dilakukan untuk mendukung kegiatan pengelolaan aset agar lebih optimal. Dalam melakukan tugasnya sebagai penatausaha BMD, SKPD X telah menempuh beberapa cara, seperti melakukan penelusuran $\mathrm{k}$ mbali aset dan melakukan melakukan cek fisik atas aset yang tidak diketahui keberadaanya, menarik kembali aset yang dikuasai oleh pihak ketiga melalui koordinasi dengan SKPD terkait (walaupun sebagiannya masih belum bisa dilakukan penarikan), melakukan pembinaan secara berkala terhadap pengurus barang, dengan mengadakan bimbingan teknis dua sa pai tiga kali setahun untuk meningkatkan pengetahuan dan kemampuan pengurus barang dalam penatausahaan aset, bahkan melakukan studi banding ke beberapa daerah yang telah meraih opini WTP. 


\section{SIMPULAN}

Pemerintah Kabupaten Sarmi belum sepenuhnya melaksanakan penatausahaan aset sesuai dengan Peraturan Menteri Dalam Negeri No 19 Tahun 2016. Aspek pembukuaan saja yang mempunyai nilai tertinggi, selanjutnya aspek pelaporan yang mempunyai nilai dan aspek inventarisasi menjadi aspek yang paling rendah dalam penatausahaan aset. Pentausahaan aset tetap yang dilakukan oleh Kabupaten Sarmi, memiliki beberapa kendala yaitu: penyalahgunaan aset, lemahnya koordinasi, kurangnya sumber daya manusian yang menangani aset, dan terbatasnya instensif bagi pengelola aset. Pemerintah Kabupaten Sarmi belum memiliki Peraturan Daerah mengenai pengelolaan Barang Milik Daerah Reviu atas regulasi yang dimiliki Pemerintah Kabupaten Sarmi serta perencanaan kebutuhan dan penganggaran Barang Milik Daerah belum memadai.

\section{DAFTAR PUSTAKA}

Arifin, Z. (2009). Evaluasi pembelajaran. Bandung: PT Remaja Rosdakarya.

Botosan, C. A., \& Huffman, A. A. (2015). Decision-useful asset measurement from a business valuation perspective. Accounting Horizons, 29(4), 757-776.

Broadbent, J., \& Guthrie, J. (1992). Changes in the Public Sector: A Review of Recent"Alternative"Accounting Research. Accounting, Auditing \& Accountability Journal, 5(2), 0.

Curran, L. M., Trigg, S. N., McDonald, A. K., Astiani, D., Hardiono, Y. M., Siregar, P., ... Kasischke, E. (2004). Lowland forest loss in protected areas of Indonesian Borneo. Science, 303(5660), 1000-1003.

Denhardt, R. B., \& Denhardt, J. V. (2003). The new public service: An approach to reform. International Review of Public Administration, 8(1), 3-10.

Hughes, C. (1998). Finding your marbles: Does preschoolers' strategic behavior predict later understanding of mind? Developmental Psychology, 34(6), 1326.

Jackson, S. E., \& Schuler, R. S. (1995). Understanding human resource management in the context of organizations and their environments. Annual Review of Psychology, 46(1), 237-264.

Koswara, A. (2001). EFEKTIVITAS PEMBERDAYAAN TIM PELAKSANA USAHA KESEHATAN DAN PENGARUHNYA TERHADAP KESEHATAN SISWA SEKOLAH DASAR: Kaus Sebagai Persyaratan Untuk Memperoleh Gelar Magister Pendidikan Program Studi Administrasi Pendidikan. Universitas Pendidikan Indonesia.

Mappeasse, M. Y. (2009). Pengaruh cara dan motivasi belajar terhadap hasil belajar 
programmable logic controller (PLC) siswa kelas III jurusan listrik SMK Negeri 5 Makassar. Jurnal Medtek, 1(2), 1-6.

Mardiasmo. (2004). good governance.

Pacini, C. J., Hopwood, W. S., \& Sinclair, D. T. (2016). Domestic asset tracing: Identifying, locating and freezing stolen and hidden assets. Journal of Forensic Accounting Research, 1(1), A42-A65.

Portales-Casamar, E., Thongjuea, S., Kwon, A. T., Arenillas, D., Zhao, X., Valen, E., ... Sandelin, A. (2010). JASPAR 2010: the greatly expanded open-access database of transcription factor binding profiles. Nucleic Acids Research, 38(suppl_1), D105-D110.

Ritonga, I. T., \& Alam, M. I. (2010). Apakah Incumbent Memanfaatkan Anggaran Pendapatan dan Belanja Daerah (APBD) Untuk Mencalonkan Kembali Dalam Pemilihan Umum Kepala Daerah (Pemilukada). Simposium Nasional Akuntansi, 13.

Suharto, T. (2012). Pendidikan Berbasis Masyarakat; Relasi Negara Dan Masyarakat Dalam Pendidikan. LKIS Pelangi Aksara. 